\title{
LINKING CULTURE, ORGANIZATIONAL LEARNING ORIENTATION AND PRODUCT INNOVATION PERFORMNACE: THE CASE OF ETHIOPIAN MANUFACTURING FIRMS
}

\author{
K.T.Beyene ${ }^{1,2 *}$, C.S. Shi ${ }^{1} \&$ W.W. $\mathrm{Wu}^{1}$
}

\section{ARTICLE INFO}

\section{Article details}

Submitted by authors 26 Aug 2015

Accepted for publication 1 Feb 2016

Available online $\quad 10$ May 2016

The authors want to thank Mekelle University (Ethiopian Institute of

Technology) for the financial support provided through the research grant, $\mathrm{EiT}-\mathrm{M} / \mathrm{RB} / 01 / 2013$.

\section{Contact details}

* Corresponding author milmatkin@hit.edu.cn

Author affiliations

1 Harbin Institute of Technology, School of Management, China

2 Department of Industrial

Engineering, Mekelle University, Ethiopia

DOI

http://dx.doi.org/10.7166/27-1-1334

\section{ABSTRACT}

Using formal survey data from textile and leather product manufacturing firms in Ethiopia, we investigate how the current national cultural setup (power distance, collectivism, masculinity and uncertainty avoidance) is affecting organizational learning, orientation and product innovation performance. Further, we assess the moderating role of sector and ownership structure on the interrelationship. The result demonstrates that the current national culture setup is negatively affecting the learning and innovation activities of the firms in the country. It also shows that while sector type is neutral, ownership type significantly affects the interrelationship among culture, learning orientation and product innovation performance.

\section{OPSOMMING}

Deur die gebruik van peilingdata van tekstiel- en leerproduk vervaardigers in Etiopië word die invloed van die huidige nasionale kulturele milieu (dit sluit die afstand tot krag, kollektivisme, manlikheid en onsekerheidsvermyding) op die organisatoriese leer, oriëntasie en produkinnovasie bestudeer. Verder word die matigende rol van sektortipe en eienaarskapstruktuur op die onderlinge verhoudinge beoordeel. Die resultaat toon dat die huidige nasionale kulturele milieu die leer- en innovasieaktiwiteite negatief beïnvloed. Dit toon ook dat, terwyl die sektortipe nie ' $n$ noemenswaardige invloed het nie, die eienaarskapstruktuur die onderlinge verhouding tussen kultuur, leeroriëntasie en produkinnovasie daadwerklik beïnvloed.

In this era of globalisation, a firm's profitability and survival in the international market is entirely dependent on continuous innovation [1]. In every economy, organisations are being forced - by intense competition, technological change, and much-reduced product lifecycles - to look for new and better ways of doing business. The generation and development of new marketable products has long been considered a key strategic advantage for an organisation's survival and its ability to outperform its competition. However, according to Martin de Castro [2], continuous innovation is impossible without a deliberate and continuous commitment to organisational learning. The effective generation, development, and commercialisation of new products is possible only if firms acquire, interpret and disseminate reliable customer, competitor and technology-related information.

From the perspective of contingency theory, the role of socio-economic and socio-cultural factors in the business operations of organisations has attracted the attention of managers and academics [3]. Consequently, the role of a country's cultural factors in the learning and innovation activity of the manufacturing firms operating within it has been the focus of much research $([4,5])$. A national culture is a collective mindset that reflects the behaviour, attitudes and norms of a society and influences the perceptions, expectations, and motivation of its members [6, 7]. 
Existing theoretical and empirical evidence shows that the level of commitment to learning, the creation of a shared vision, and the level of openness in an organisation are largely influenced by the culture of the territory within which they. Studies also show that the national culture, through its influence on the learning orientation of organisations, influences firms' attitude to innovation and its performance in innovation [3].

However, regardless of the extensive studies that credit both national culture and learning orientation with influencing product innovation performance, only limited studies consider the effect of the interplay between the two constructs on the performance of firms. Furthermore, many of the conclusions are drawn either from cases in a purely Western cultural environment or from cross-cultural comparative studies [8]. Consequently, the applicability of these studies to the cultural context of less-developed countries is questioned by many scholars [3, 9]. Thus this paper, in studying manufacturing firms in Ethiopia, investigates the impact of Hofstede's four cultural dimensions (power distance, collectivism vs individualism, femininity vs masculinity, and uncertainty avoidance $[6,10])$ on learning orientation and product innovation performance. Moreover, it examines whether the type of sector and of ownership have an effect on these relationships.

Following the remarkable economic growth between 1992 and 2010, Ethiopia has become the hub of foreign direct investment in Africa. Thus a prior country-specific understanding of the impact of national culture on business activities might help the development of competitive advantage, and serve as a practical guide to future investment in the country. This paper will also help management to gain a better understanding of the type of organisational culture that should be cultivated to counteract the detrimental effects of a national culture. From a theoretical perspective, this paper will make an incremental contribution to the existing literature. It develops a detailed model that defines innovation performance in terms of two elements: project performance and commercial performance. While project performance is concerned with the internal efficiency of the innovation process (measured in terms of speed, quality, and cost), commercial performance is related to the market success of newly-introduced products (related to financial gains and level of customer satisfaction). Thus the model will be an alternative tool for analysing similar cases in the future. However, due to lack of published works related to the impact of the national culture on the performance Ethiopian manufacturing firms, more work will be needed to have a generalizable conclusion.

\section{LITERATURE REVIEW AND HYPOTHESES}

\subsection{Product innovation performance}

To outperform in the current highly competitive market, manufacturing firms need consciously to introduce new products faster and at lower cost [11, 12]. Consequently, innovation performance is not only about how successful newly-introduced products are in the market, but also about the success and efficiency of the innovation process itself $[13,14]$. Product innovation performance, according to Menguc and Auh [15], is a continuous organisational performance measured by the commercial outcome, the level of customer satisfaction, and the overall project performance of the innovation process. Based on the definition of Menguc and Auh [15], this paper sees product innovation performance as the combination of project performance and commercial performance. Commercial performance is the market success of a new product related to the organisation's financial gain and the level of customer satisfaction created by its introduction [15, 16]. Project performance, on the other hand, is concerned with the internal efficiency of the innovation process. Project performance is the total effort an organisation invests in the innovation process, and is revealed through the speed of innovation, the quality of the final product, and the overall cost reduction effort $[2,17]$.

\subsection{Organisational learning orientation and product innovation performance}

Innovation is a knowledge-intensive process that entirely depends on the acquisition, interpretation, and dissemination of customer, competitor and technology-related information. Senge [18] showed that business firms that are highly committed to learning will organise themselves in a way that continuously supports the effort to outperform the competition. According to Dicle and Kose [19], deliberate and continuous learning adds flexibility to an organisation's effort to generate and commercialise new products. The learning orientation is an organisational process of creating customer- and competitor-related knowledge, and determining 
the method of collecting, sharing and interpreting the obtained knowledge [20, 21]. A welldesigned organisational learning orientation - supported by learning objectives, a continuous commitment of resources, and a culture of information-sharing - serves its purpose well.

According to Sinkula and Baker [22], the learning orientation has three components: the commitment to learn, a shared vision, and open-mindedness. An organisation's commitment to learning is shown in its emphasis on the value of learning, and in remaining committed to it. On the other hand, an organisation's open-mindedness is the extent of organisational openness to accept change and to adopt new ways of doing business. According to Donate and De Pablo [23], an organisation's open-mindedness is also seen in its willingness to question long-held assumptions and beliefs and to unlearn them if necessary. The creation of an organisation-wide shared vision guides what an organisation learns, and how it learns [24].

According to Wheeler [25], the learning activity of an organisation is an embedded part of the innovation process that enables the firm to create products of higher value for customers. In addition, Wang [26] shows empirically that organisations that give undivided attention to learning and that are organised to support it continuously perform better than their counterparts. Learning not only enables firms to commercialise newly-developed products successfully, but also increases their efficiency in new-product generation and in the development process [11, 12]. In support of this notion, Jimenez and Valle [27] state that the faster an organisation learns, the better will be its control of the speed, quality and cost of the innovation process. Consequently, this paper argues that the learning activity of an organisation positively influences the project performance and the commercial performance of its innovation process. Thus:

Hypothesis 1: The learning orientation of an organisation has a positive relationship with both the project performance and the commercial performance of its innovation process.

\subsection{National culture, organisational learning and innovation performance}

'Culture' encompasses different dimensions, making it difficult to single out a specific definition. Researchers in different fields define 'culture' in various ways. The most widely-used definition is that of Hofstede [6], that culture is the "collective programming of mind which distinguishes one group or category of people from others.....it influences the group's response to change in its environment".

Along with this definition, Hofstede's four dimensions of culture - power distance, collectivism vs individualism, femininity vs masculinity, and uncertainty avoidance $[6,10]$-became popular among researchers $[9,28]$. According to Newburry and Yakova [29], Hofstede's cultural dimension were found to be valuable, stable and reliably for the analysis cultures of different territories. The notion was also shared by Kirkman [30] that, even though these four dimensions of culture were criticised by many scholars, they were widely used because of their clarity and their meaningfulness to managers.

The existing literature shows that the culture of a nation both directly and indirectly influences the business strategy and activities of organisations operating within it [9,31,32]. The notion was also shared by Troy et al. [33] that the culture surrounding an organisation, and the resulting organisational culture, determine the behaviour and interaction of individual members of the organisation. According to Vecchi and Brennan [5], a national culture, through its influence on the perceptions, expectations and motivation of members of organisations, influences both individual and organisational performance. Moreover, the four dimensions of culture were found to relate to the efficiency of the innovation process and to influence the commercialisation of new products. Supporting this notion, Shane [34] suggested that each of the four dimensions individually predicts an organisation's tendency to support learning, innovativeness, and innovation performance. Consequently, this paper investigates the impact of the four dimensions of culture on the learning orientation and product innovation performance of manufacturing firms operating in Ethiopia. The conceptual model is shown in Figure 1.

\subsubsection{Power distance and product innovation performance}

Power distance measures the extent of acceptance of power inequality in a group: the higher the power gap, the more hierarchical the structure at the national and organisational level [1]. According to Tihanyi et al. [7] and Mihet [35], business firms in high power distance cultures have highly formalised and rigid organisational structures that leave little room for employee 
participation. The difference in how power is concentrated creates a difference in the expectations and level of commitment of members of an organization, which in turn affects individual and group learning outcomes and performance [6]. In high power distance cultures, while managers rely on rules and procedures, subordinates are guided by their supervisors' orders about what to do and how to do it [28, 36]. According to Jones and Davies [37], manufacturing firms operating within such a culture exercise higher management control and less lateral communication. The phenomenon in turn reduces the creativity of individuals and the overall performance of the firm. Hence, with respect to the current cultural set-up in Ethiopia, we hypothesised as follows:

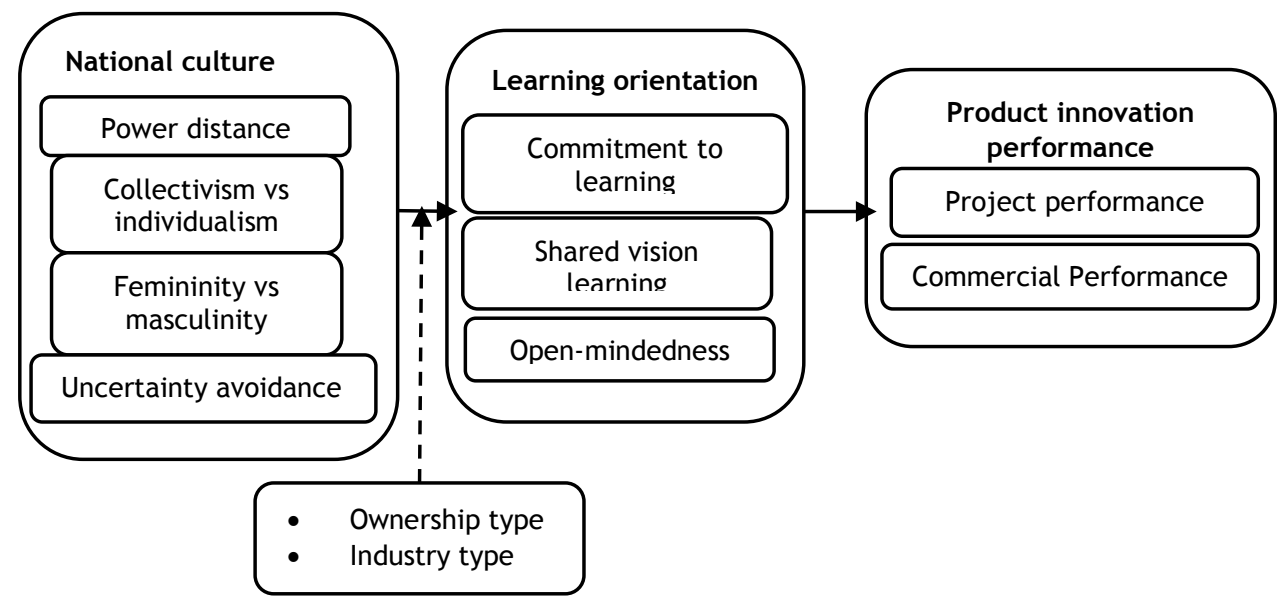

Figure 1: Conceptual model

Hypothesis 2a: A high power distance culture is negatively related to the learning orientation of manufacturing firms.

Hypothesis 2b: A high power distance culture, through its influence on learning orientation, is negatively correlated to the innovation performance of manufacturing firms.

\subsubsection{Collectivism vs individualism and product innovation performance}

'Collectivism vs individualism' refers to the degree to which group thinking overrules individual thinking and practice [1]. Due to its long-standing religious character, Ethiopian culture mostly encourages tight social ties and collective action among members. This is reflected in the cultural evaluation module of Hofstede [6] in which Ethiopia scores 80 for collectivism. According to Hofstede [32], countries with a tight social framework prioritise group communication and the allegiance of individuals to a group. Consequently, business firms operating within a culture with a high level of collectivism encourage the presence of shared values and goals within a team [38].

As for the impact of collectivism on learning orientation, innovativeness, and innovation performance, the literature draws different conclusion. A study by Hofstede [6] indicates that, in a highly collectivist culture, individuals will have limited room for creativity and that their job satisfaction and performance will be lower. On the other hand, studies that consider eastern cultures have found that a collectivist culture creates better inter-functional integration in an organisation, along with and smooth information flow and learning [14,39, 40]. Olson et al. [41] agreed that collectivist cultures enable members of organisations to have more information about the market and to enhance their performance. Hence, considering the conclusion of the latter group, we hypothesise the following:

Hypothesis 3a: The high collectivist culture in Ethiopia is positively related to the learning orientation of manufacturing firms.

Hypothesis 3b: The high collectivist culture in Ethiopia, through its influence on learning orientation, is positively related to the innovation performance of manufacturing firms.

\subsubsection{Femininity vs masculinity and product innovation performance}

'Femininity vs masculinity' refers to the pattern of gender dominance in a group. According to Efrat [1], more masculine cultures exhibit unbalanced roles between men and women in societiy. Studies indicate that highly masculine cultures are characterised by ego, higher achievement, and high risk-taking [6, 42]. Because of the need for high achievement, social recognition, and 
financial earnings, employees in firms operating in such cultures are more ready to learn about their environment, are more creative, and are high performers. This, according to Efrat [1], is especially true for manufacturing firms with both financial and non-financial motivation schemes. Therefore, with respect to the Ethiopian cultural perspective, we hypothesise as follows:

Hypothesis 5a: The masculinity characteristic of a culture has a positive influence on the learning orientation of manufacturing firms in that culture.

Hypothesis 5b: The high masculinity culture of a country, though its positive influence on learning orientation, is positively correlated to the product innovation performance of manufacturing firms.

\subsubsection{Uncertainty avoidance and product innovation performance}

Uncertainty avoidance' indicates the degree to which members of a society are threatened by ambiguous situations and how they attempt to solve them [33]. Societies with high uncertainty avoidance are characterised by high levels of inflexibility and a high resistance to change [1,3]. According to Dimitratos et al. [9], manufacturing firms operating within a culture of high uncertainty avoidance are usually characterised by formal structures where rules and regulations control the rights and duties of members of the organisation. Because of their dependence on rules and regulations, members will be reluctant to take risks and will be discouraged to use creativity in solving problems. Related to this, the findings of House et al. [40] suggest that, because of the high uncertainty associated with innovation, firms operating within cultures of high uncertainty avoidance will have lower innovation performance. Hence:

Hypothesis 4a: The high uncertainty avoidance culture in Ethiopia is negatively related to the learning orientation of manufacturing firms.

Hypothesis 4b: The high uncertainty avoidance culture in Ethiopia, through its influence on learning orientation, is negatively related to the product innovation performance of manufacturing firms.

\subsubsection{The moderating role of sector and ownership type}

Many scholars of management theory agree that management's perception of the business environment of an organisation is more influential than the environment itself [43, 44]. Because of differences in management's perception, different firms develop different strategies, structures, and cultures. According to Damanpour [45], the rate of strategic, structural and cultural adaptation in turn influences the rate and speed of learning and innovation in an organisation. The work by Hult et al. [46] suggests that, because of cultural outcomes, different industries have different attitudes to learning and innovation. In addition to the sector type, the type of ownership and structure also influence an organisation's tendency to learn and innovate. A very recent finding by Song et al. [47] suggests that, because of its influence on the behaviour of the members of an organisation, ownership moderates the firm's activities. Li, Chau and Lai [48] also found that the type of ownership of a firm moderates factors that have an impact on product innovation performance. In general, these studies acknowledge that public firms usually have formal structures and firm rules and regulations, and so are more bureaucratic than their private counterparts. According to Song et al. [48], compared with privately-owned firms, public manufacturing firms are considerably more averse to risk, less proactive, and more short-term oriented. Thus it is highly likely that the national culture has a more negative impact on public companies than it does on privately-owned ones. Thus the last two hypotheses probe whether sector type and ownership type moderate the effect of a national culture on learning orientation and product innovation performance.

Hypothesis 6: Sector type has a significant moderating role in the interrelationship between culture, learning orientation, and product innovation performance.

Hypothesis 7: Ownership type has a significant moderating role in the interrelationship between culture, learning orientation, and product innovation performance.

\section{METHODOLOGY}

\subsection{Sample and data collection}

The research for this paper used mail survey data from textile and leather product manufacturing firms in Ethiopia. Under Ethiopia's development and industrialisation policy, which come into effect in 2010, the government placed its undivided focus on agriculture-led manufacturing [49]. Accordingly, the textile and leather subsectors were given preferential treatment for three 
economic reasons. First, both sectors receive massive input from local agricultural products (cotton and livestock). Second, they use a great deal of low- and middle-skilled labour, thus meeting the goal of wealth creation. Third, export from the sectors formed part of the solution to the country's serious foreign currency reserve problem [49].

As they are well-informed members of their organisations, this paper regards the top and middle management of each participating firm as key informants [50, 51]. In order to make the information as comprehensive and reliable as possible, we collected data from managers who exercised different functions [14]. Before the survey itself, the questionnaire containing measurement items from the existing literature was thoroughly validated and pre-tested through interviews with academic experts and senior members of management. Following Dillman [52], ten questionnaires, along with a covering letter stating the objective of the study and a prepaid envelope, were sent to the human resources department of each organisation, for distribution among the members of management. At the end of the second week of the first distribution, a second wave of questionnaires was sent to each participating firm as a reminder. The effective response rate was 29 per cent, which included 286 responses from textile manufacturers and 146 from leather product manufacturers.

\subsection{Measurement}

The measurement items for all the constructs in Figure 1 were adapted from the existing literature, and are described below.

National culture: Items related to the four cultural dimensions of Hofstede - power distance, collectivism vs. individualism, certainty avoidance, and masculinity vs femininity - were adopted from Rhyne et al. [53]. Respondents were asked to evaluate the level of influence of the chosen cultural factors on the firms' learning orientation and performance. All items were measured on a five-point Likert scale ranging from ' 1 ' (= very low) to ' 5 ' (= very high).

Organisational learning orientation is the level of emphasis and commitment that an organisation has towards the importance of customer- and competitor-related learning. Measurement items focusing on the commitment to learning, open-mindedness, and shared vision were taken from Zakic et al. [12] and Chen \& Huang [54]. Items were measured on a five-point Likert scale ranging from ' 1 ' (= strongly disagree) to ' 5 ' (= strongly agree).

Product innovation performance comprises both the project performance and the commercial performance of a firm. Project performance reflects the efficiency and effectiveness of the innovation process measured in terms of speed, quality and the cost reduction efforts of a firm's innovation process [11, 12]. Commercial performance, on the other hand, is related to the market success of newly-introduced products measured in terms of the financial gains and the level of satisfaction it brought the customer [24]. Measurement items were adapted from Wang \& Wang [51] and Bodlaj [55]. On a five-point Likert scale ranging from ' 1 ' (= totally disagree) to ' 5 ' (= totally agree), respondents were asked to compare the innovation performance of their firm relative to its key competitors.

Moderating variables: The paper considers sector type and ownership type as moderating variables in the impact of culture on learning orientation and product innovation performance. The paper uses a dummy variable of ' 1 ' (= textile) and ' 2 ' (= leather) for sector type, and ' 0 ' (= public) and ' 1 ' (= private) for ownership type.

\section{$4 \quad$ RESULT}

The correlation matrix in Table 1 is an indication of the presence of significant relationships between national culture and an organisation's learning orientation and product innovation performance. In general, the correlation matrix supports the hypotheses.

To further measure the overall relationship among the components of the three constructs, this paper uses the maximum likelihood estimation of structural equation modelling (SEM) with Amos version 21.0. Due to its ability to support range of theoretical interrelationships and the possibility of simultaneous measurement error analysis, management researchers are increasingly using SEM $[56,57]$. After checking for multivariate normality and linearity [58], the structural model uses the average of each respondent values to estimate the path coefficients. 


\subsection{Scale validity and reliability}

The psychometric properties of both the measurement and the structural models were checked by using acceptable criteria [58, 59]. The validity and reliability of the measurement scale was evaluated by discriminant validity, convergent validity, and content validity tests.

Table 1: Descriptive statistics and discriminant validity test result

\begin{tabular}{lccccccccr}
\hline Mean & 3.57 & 3.64 & 3.47 & 3.72 & 3.27 & 3.48 & 3.46 & 3.49 & 3.46 \\
SD & 0.65 & 0.64 & 0.69 & 0.77 & 0.85 & 0.73 & 0.78 & 0.65 & 0.64 \\
\hline Construct & OPDI & COLL & UNAV & MASC & COLE & SHVI & OPMI & PRPE & COPE \\
\hline OPDI & $\mathbf{0 . 8 0}$ & & & & & & & & \\
COLL & $-0.62^{* *}$ & $\mathbf{0 . 8 1}$ & & & & & & & \\
UNAV & $0.10^{*}$ & $0.26^{* *}$ & $\mathbf{0 . 8 2}$ & & & & & & \\
MASC & $0.42^{* *}$ & $-0.42^{* *}$ & $-0.14^{* *}$ & $\mathbf{0 . 8 1}$ & & & & & \\
COLE & $-0.27^{* *}$ & $-0.25^{* *}$ & $-0.31^{* *}$ & $0.28^{* *}$ & 0.78 & & & & \\
SHVI & $-0.24^{* *}$ & $0.39^{* *}$ & $-0.23^{* *}$ & $-0.24^{* *}$ & $0.29^{* *}$ & 0.84 & & & \\
OPMI & $-0.28^{* *}$ & $-0.15^{* *}$ & $-0.25^{* *}$ & $-0.23^{* *}$ & $0.14^{* *}$ & $0.36^{* *}$ & 0.72 & & \\
PRPE & $-0.12^{* *}$ & $-0.20^{* *}$ & $-0.56^{* *}$ & $0.30^{* *}$ & $0.36^{* *}$ & $0.23^{* *}$ & $0.54^{* *}$ & 0.79 & \\
COPE & $-0.64^{* *}$ & $-0.29^{* *}$ & $-0.26^{* *}$ & $-0.37^{* *}$ & $0.36^{* *}$ & $0.30^{* *}$ & $0.38^{* *}$ & $0.52^{* *}$ & $\mathbf{0 . 7 9}$ \\
\hline
\end{tabular}

The convergent validity was tested by using factor loading, composite reliability (CR), and average variance extracted (AVE). (Consult Wang and Wang [51] and Kline [58] for more information.) As shown in Table 2, the factor loadings, the CR, and the AVE values exceeded the threshold points indicated in the literature ([51] for example). The discriminant validity was evaluated by comparing the square root of the AVE for each construct with its correlation values with the other constructs [59]. The measurement scale was also tested for content validity by using the coefficient alpha ( $C$ - $a$ ) values (see Table 1 ). By using different fit indicies, we also evaluated the data-model fit of the the structural model. The test was based on absolute fit measurement values (chi-square, $\mathrm{x}^{2}$; degree of freedom, df; goodness of fit index, GFI; and root mean square error approximation, RMSEA) and incremental fit measurements values (normed fit index, NFI; nonnormed fit index, NNFI, and comparative fit index, CFI). All the fit indicies met the criteria mentioned in the literature [51, 58]. Thus the structural model fitted the survey data well (see Table 3).

\subsection{Hypotheses test}

The hypothetical model considers Hofstede's four cultural dimension - power distance, collectivism vs. individualism, masculinity vs. femininity and uncertainty avoidance [6, 10] - as direct antecedents to organisational learning orientation, while product innovation performance was used in the analysis of the interactions. The total direct and indirect effect decomposition results provided in Table 3 indicate that all the interaction values are significant. The overall model explains 46 per cent of the variance with respect to project performance, and 60 per cent of variance in commercial performance.

We first tested the hypothesis about the relationship of the three learning orientation components to the two components of product innovation performance. The effect decomposition result in Table 3 indicates that the three components of organisational learning orientation, commitment to learning $\left(B_{P R P E}=0.35, p<0.01, B_{C O P E}=0.15, p<0.01\right)$, shared vision $\left(B_{P R P E}=0.83, p<0.01, B_{C O P E}=0.35\right.$, $p<0.01)$ and open-mindedness $\left(B_{\mathrm{PRPE}}=0.29, p<0.01, B_{\mathrm{COPE}}=0.18, p<0.01\right)$ are significantly and positively related to both project and commercial performance of the innovation process. Thus the first hypothesis was fully supported.

Consistent with the hypotheses, high power distance was found to have a significantly negative effect on learning orientation and product innovation performance. Power distance exerts a direct effect of $\left(B_{\mathrm{COLE}}=-0.72, p<0.01\right),\left(B_{\mathrm{SHVI}}=-0.79, \mathrm{p}<0.01\right)$, and $\left(B_{\mathrm{OPMl}}=-0.66, \mathrm{p}<0.01\right)$ on commitment to learning, shared vision, and open-mindedness respectively. Similarly, power distance was found to have an indirect effect of $\left(B_{\mathrm{PRPE}}=-0 .-88, \mathrm{p}<0.01\right)$ on project performance and $\left(B_{\mathrm{COPE}}=-0.71\right.$, $\mathrm{p}<0.01$ ) on commercial performance. Thus Hypotheses $2 \mathrm{a}$ and $2 \mathrm{~b}$ were fully supported. The analysis result demonstrated that the collectivism dimension of the national culture negatively impacts on both learning commitment $\left(B_{\text {COLE }}=-0.67, p<0.01\right)$ and open-mindedness $\left(B_{O P M I}=-0.66\right.$, $\mathrm{p}<0.01)$, but that it has a significantly positive impact on shared vision $\left(B_{S \mathrm{SVl}}=0.58, p<0.01\right)$. Furthermore, while it has an indirect effect of $\left(B_{P R P E}=0.52, p<0.01\right)$ on project performance, it has a significant negative indirect effect of $\left(B_{C O P E}=-0.33, p<0.01\right)$ on commercial performance. 
Overall, the hypotheses about the impact of collectivism on learning orientation and product innovation performance (Hypotheses $\mathbf{3 a}$ and $\mathbf{3 b}$ ) were not supported in the case of Ethiopia.

Masculinity was hypothesised to have a positive effect on the learning orientation and product innovation performance components. With respect to the learning orientation components, while masculinity impacts negatively on shared vision $\left(B_{\mathrm{SHVI}}=-0.63, p<0.01\right)$ and open-mindedness $\left(B_{\mathrm{OPMI}}=\right.$ $-0.60, p<0.01)$, it has a significantly positive impact on commitment to learning $\left(B_{\mathrm{COLE}}=0.74\right.$, $p<0.01)$. Similarly, collectivism has an indirect effect of $\left(B_{P R P E}=0.26, p<0.01\right)$ and $\left(B_{C O P E}=-0.21\right.$, $\mathrm{p}<0.05$ ) on project performance and commercial performance respectively. Thus the hypotheses in this case are only partially supported. As expected and hypothesised, the high uncertainty avoidance culture in Ethiopia has a significantly negative impact on the learning and innovation performance of the manufacturing firms. The analytical result shows that uncertainty avoidance has a direct effect of $\left(B_{\text {COLE }}=-0.23, p<0.01\right)$ on commitment to learning, $\left(B_{S H V I}=-0.53, p<0.01\right)$ on shared vision, and $\left(B_{O P M I}=-0.24, p<0.01\right)$ on open-mindedness. Similarly, it has an indirect effect of $\left(B_{\mathrm{PRPE}}=-0.52, p<0.01\right)$ on project performance and $\left(B_{\mathrm{COPE}}=-0.15, p<0.01\right)$ on commercial performance. Thus the result fully supports Hypotheses $5 \mathrm{a}$ and $\mathbf{5 b}$.

Finally, we evaluate the influence of both sector and ownership type on the interrelationship between the cultural elements and product innovation performance. Generally speaking, the result did not provide supportive evidence for the presence of a sector-based difference in the effect of the national culture. However, a visible difference was observed in the effect of uncertainty avoidance on learning orientation (shared vision and open-mindedness) and on both project and commercial performances (see Table 4). On the other hand, the result fully supports the hypotheses related to the moderation effect of ownership type on the effect of culture. The effect of decomposition result in Table 4 (Model 2) indicates that the national culture has a more detrimental effect on the learning orientation and innovation performance of public firms than on their private counterparts.

\section{DISCUSSION}

The main aim of this study was to investigate the impact of Ethiopia's national culture on the learning orientation and product innovation performance of manufacturing firms in that country. It explored the extent and direction of the impact of Hofstede's four cultural dimensions [6, 10] on the commitment to learning, shared vision, and open-mindedness of the firms. It also examined the indirect effect of each cultural dimension on the product and commercial performance components of the firms' innovation process. Hofstede's four cultural dimensions - power distance, individualism vs collectivism, femininity vs masculinity, and uncertainty avoidance - have often received attention in management-focused research. Hofstede's cultural characterisation have proved to be reliable for cases in a variety of cultural and national contexts [29] and to be clear and meaningful for management in different sectors [30]. Furthermore, according to Shane [34], the four cultural dimensions were each found to predict an organisation's attitude towards learning and innovation practice.

This study was initiated by (1) the need for a country-specific study of the interrelationship between culture, learning, and product innovation; (2) a need to create a better and detailed understanding of the relationship between each cultural dimension and the commitment to learning, shared vision, and open-mindedness of manufacturing firms; and (3) the need to understand the effect of the interaction of culture and learning orientation on the firms' project and commercial performance of the innovation process.

The analysis has demonstrated that the hypothetical model that relates culture, learning orientation and product innovation performance closely matches the survey data. The significance of the relationship between the antecedent (national cultural dimensions) and learning orientation, as well as the consequences (project and commercial performance) and learning orientation, were indications of the significance of the mediating role of learning orientation. Subsequently, the effects of the four cultural dimensions on project and commercial performance were found to be fully mediated by a commitment to learning, shared vision, and openmindedness. The finding is therefore an indication that culture alone is not a factor that affects the business activities of organisations, but that it is manifested through other management practices. In this case, culture shapes the behaviour of the members of an organisation, and through its influence on their perceptions, motivation, and expectations, it influences both the individual's and the group's attitude to learning and innovation [5, 54]. 
The culture of high power distance in Ethiopia, which in turn has implications for the remaining cultural dimensions [1], was found to have a dominant negative effect on the learning orientation and innovation performance of the firms in that country. Consistent with the hypotheses, we also found that the high culture of uncertainty avoidance is reflected in the structure of the firms and affects the results of their learning and innovation efforts. This finidng was consistent with the literature that has found that firms operating in a high power distance culture have a very rigid structure that leaves little room for employee participation [7, 28]. The lack of lateral communication in such formal structures reduces the commitment of employees to organisational learning, and the resulting work-related dissatisfaction reduces their performance [35, 37]. On the other hand, the formality of the structure, the top-down communication, and the adherence to rules and regulations were reflected in the culture of high uncertainty avoidance, and reduced the efforts of learning and creativity in the organisations [32, 60].

Table 2: Validity and reliability test results

\begin{tabular}{|c|c|c|c|c|c|}
\hline Construct & Items & $\begin{array}{l}\text { Factor loading } \\
\text { (t-value) }\end{array}$ & $C-a$ & CR & AVE \\
\hline \multirow[t]{4}{*}{ Power distance (PODI) } & PODI1 & $0.74\left(10.708^{* *}\right)$ & 0.88 & 0.82 & 0.64 \\
\hline & PODI2 & $0.77\left(11.862^{* *}\right)$ & & & \\
\hline & PODI3 & $.90\left(11.581^{* *}\right)$ & & & \\
\hline & PODI4 & 0.81 (r.i.) & & & \\
\hline \multirow[t]{4}{*}{ Collectivism (COLL) } & COLL1 & $0.93\left(17.654^{* *}\right)$ & 0.84 & 0.64 & 0.66 \\
\hline & COLL2 & $0.73\left(14.836^{* *}\right)$ & & & \\
\hline & COLL3 & $0.82\left(9.802^{* *}\right)$ & & & \\
\hline & COLL4 & 0.78 (r.i.) & & & \\
\hline \multirow[t]{4}{*}{ Uncertainty avoidance (UNAV) } & UNAV1 & 0.77 (r.i.) & 0.83 & 0.78 & 0.68 \\
\hline & UNAV2 & $0.80\left(5.195^{* *}\right)$ & & & \\
\hline & UNAV3 & $0.90\left(5.515^{* *}\right)$ & & & \\
\hline & UNAV4 & $0.76\left(4.426^{* *}\right)$ & & & \\
\hline \multirow[t]{4}{*}{ Masculinity (MASC) } & MASC1 & 0.88 (r.i.) & 0.76 & 0.84 & 0.65 \\
\hline & MASC2 & $0.78\left(5.292^{* *}\right)$ & & & \\
\hline & MASC3 & $0.95\left(6.286^{* *}\right)$ & & & \\
\hline & MASC4 & $0.80\left(5.758^{* *}\right)$ & & & \\
\hline \multirow[t]{4}{*}{ Commitment to learn (COLE) } & COLE1 & $0.70\left(4.602^{* *}\right)$ & 0.78 & 0.76 & 0.61 \\
\hline & COLE2 & $0.78\left(5.579^{* *}\right)$ & & & \\
\hline & COLE3 & $0.75\left(6.780^{* *}\right)$ & & & \\
\hline & COLE4 & 0.73 (r.i.) & & & \\
\hline \multirow[t]{4}{*}{ Shared vision (SHVI) } & SHVI1 & $0.98\left(10.563^{* *}\right)$ & 0.72 & 0.72 & 0.69 \\
\hline & SHVI2 & 0.88 (r.i.) & & & \\
\hline & SHVI3 & $0.79\left(15.206^{* *}\right)$ & & & \\
\hline & SHVI4 & $0.93\left(5.758^{* *}\right)$ & & & \\
\hline \multirow[t]{4}{*}{ Open-mindedness (OPMI) } & OPMI1 & 0.68 (r.i.) & 0.78 & 0.75 & 0.70 \\
\hline & OPMI2 & $0.73\left(4.621^{* *}\right)$ & & & \\
\hline & OPMI3 & $0.76\left(8.509^{* *}\right)$ & & & \\
\hline & OPMI4 & $0.74\left(9.630^{* *}\right)$ & & & \\
\hline \multirow[t]{9}{*}{ Project performance (PRPE) } & INQU1 & 0.72 (r.i.) & 0.80 & 0.78 & 0.63 \\
\hline & INQU2 & $0.75\left(5.440^{* *}\right)$ & & & \\
\hline & INQU3 & $0.86\left(8.370^{* *}\right)$ & & & \\
\hline & INSP1 & 0.81 (r.i.) & & & \\
\hline & INSP2 & $0.93\left(8.633^{* *}\right)$ & & & \\
\hline & INSP3 & $0.80\left(5.495^{* *}\right)$ & & & \\
\hline & COST1 & 0.79 (r.i.) & & & \\
\hline & COST2 & $0.83\left(6.945^{* *}\right)$ & & & \\
\hline & COST3 & $0.79\left(6.671^{* *}\right)$ & & & \\
\hline \multirow[t]{6}{*}{ Commercial performance (COPE) } & FIPE1 & 0.72 (r.i.) & 0.71 & 0.70 & 0.62 \\
\hline & FIPE2 & $0.78\left(17.373^{* *}\right)$ & & & \\
\hline & FIPE3 & $0.79\left(16.859^{* *}\right)$ & & & \\
\hline & CUSA1 & 0.67 (r.i.) & & & \\
\hline & CUSA2 & $0.88\left(18.220^{* *}\right)$ & & & \\
\hline & CUSA3 & $0.74\left(16.622^{* *}\right)$ & & & \\
\hline
\end{tabular}

Following the findings of the existing literature (see, for example, [39] and [42]) we were expecting significant and positive effects caused by collectivism and masculinity. However, the analysis showed that, while collectivism has a positive significant effect on the creation of shared interpretation, its effect on an organisation's commitment to learning and open-mindedness was found to be negative. The significantly positive effect of collectivism on shared vision was consistent with other findings [14, 39]. Because the high collectivist culture makes it easier to 
obtain documents and information, it might create favourable conditions for the creation of a shared organisational vision. In a society that encourages a culture of high power distance and high uncertainty avoidance, the negative effect of collectivism on commitment to learning and openmindedness is also acceptable. Similarly, collectivism was found to have an indirect effect of $\left(B_{P R P E}=0.52, p<0.01\right)$ on project performance and $\left(B_{\text {COPE }}=-0.33, p<0.01\right)$ on commercial performance. In this case, the difference in the effect on project and commercial performance is a reflection of its effect on the learning orientation components. A similar pattern of effect was demonstrated from the masculinity dimension. In this case, while masculinity positively affects commitment to learning, it has a significantly negative effect on shared vision and openmindedness. Following Cantwell [42] and Hofstede [6], individuals in a highly masculine culture are triggered by the sense of achievement to have a higher commitment to learning. Organisational members with such a commitment to learn new things and to achieve more are risk-takers and high project performers. This can be seen from the significantly positive effect on project performance. While individual performance affects the overall project performance of an organisation's innovation process, commercial performance is clearly an organisation-wide process. Consequently, the negative influence of the masculinity dimension is related to the influence of the power distance and collectivism dimensions.

Table 3: Effect decomposition: Total path model

\begin{tabular}{|c|c|c|c|c|c|}
\hline & Path & & Total effect & Direct effect & Indirect effect \\
\hline PODI & $-->$ & COLE & $-0.72\left(-6.78^{* *}\right)$ & $-0.72\left(-6.78^{* *}\right)$ & \\
\hline PODI & --> & SHVI & $-0.79\left(-7.43^{* *}\right)$ & $-0.79\left(-7.43^{* *}\right)$ & \\
\hline PODI & --> & OPMI & $-0.66\left(-7.38^{* *}\right)$ & $-0.66\left(-7.38^{* *}\right)$ & \\
\hline COLL & $->$ & COLE & $-0.67\left(-4.13^{* *}\right)$ & $-0.67\left(-4.13^{* *}\right)$ & \\
\hline COLL & --> & SHVI & $0.58\left(5.60^{* *}\right)$ & $0.58\left(5.60^{* *}\right)$ & \\
\hline COLL & -.> & OPMI & $-0.66\left(-3.29^{* *}\right)$ & $-0.66\left(-3.29^{* *}\right)$ & --- \\
\hline MASC & -.> & COLE & $0.74\left(7.11^{* *}\right)$ & $0.74\left(7.11^{* *}\right)$ & -.- \\
\hline MASC & -.> & SHVI & $-0.63\left(-5.50^{* *}\right)$ & $-0.63\left(-5.50^{* *}\right)$ & -.- \\
\hline MASC & --> & OPMI & $-0.60\left(-7.67^{* *}\right)$ & $-0.60\left(-7.67^{* *}\right)$ & -.- \\
\hline UNAV & --> & COLE & $-0.23\left(-5.00^{* *}\right)$ & $-0.23\left(-5.00^{* *}\right)$ & --- \\
\hline UNAV & --> & SHVI & $-0.53\left(-7.25^{* *}\right)$ & $-0.53\left(-7.25^{* *}\right)$ & -.- \\
\hline UNAV & --> & OPMI & $-0.24\left(-4.20^{* *}\right)$ & $-0.24\left(-4.20^{* *}\right)$ & --- \\
\hline COLE & --> & PRPE & $0.33\left(3.25^{* *}\right)$ & $0.33\left(3.25^{* *}\right)$ & -.. \\
\hline COLE & --> & COPE & $0.15\left(2.67^{* *}\right)$ & $0.15\left(2.67^{* *}\right)$ & $\cdots$ \\
\hline SHVI & --> & PRPE & $0.83\left(8.56^{* *}\right)$ & $0.83\left(8.56^{* *}\right)$ & $\cdots$ \\
\hline SHVI & --> & COPE & $0.35\left(7.20^{* *}\right)$ & $0.35\left(7.20^{* *}\right)$ & $\cdots$ \\
\hline OPMI & --> & PRPE & $0.29\left(4.67^{* *}\right)$ & $0.29\left(4.67^{* *}\right)$ & --- \\
\hline OPMI & --> & COPE & $0.18\left(4,75^{* *}\right)$ & $0.18\left(4,75^{* *}\right)$ & -.- \\
\hline PODI & --> & PRPE & $-0.88\left(-7.54^{* *}\right)$ & -.. & $-0.88\left(-7.54^{* *}\right)$ \\
\hline PODI & --> & COPE & $-0.71\left(-7.67^{* *}\right)$ & -.. & $-0.71\left(-7.67^{* *}\right)$ \\
\hline COLL & --> & PRPE & $0.52\left(8.17^{* *}\right)$ & -.- & $0.52\left(8.17^{* *}\right)$ \\
\hline COLL & -.> & COPE & $-0.33\left(-7.74^{* *}\right)$ & -.. & $-0.33\left(-7.74^{* *}\right)$ \\
\hline MASC & $-->$ & PRPE & $0.26\left(2.75^{* *}\right)$ & $\cdots$ & $0.26^{\prime}\left(2.75^{* *}\right)$ \\
\hline MASC & -.> & COPE & $-0.21\left(-2.56^{*}\right)$ & ..- & $-0.21\left(-2.56^{*}\right)$ \\
\hline UNAV & --> & PRPE & $-0.52\left(-4.96^{* *}\right)$ & -.. & $-0.52\left(-4.96^{* *}\right)$ \\
\hline UNAV & -.> & COPE & $-0.15\left(-2.86^{* *}\right)$ & -.. & $-0.15\left(-2.86^{* *}\right)$ \\
\hline
\end{tabular}

As for the moderating role of sector type and ownership type on the interrelationship between culture, organisational learning orientation, and product innovation performance, we found an interesting result. In this case, while the effect of culture on both an organisation's learning orientation and its product innovation performance is almost neutral of sector type, ownership type was found to have a significant influence. Accordingly, the public sector experiences more damaging effects from the current cultural setup of the nation than do their private counterparts. The result demonstrates that, relatively speaking, public manufacturing firms in Ethiopia have a higher power distance and are bound by a culture of higher uncertainty avoidance. These effects were also equally reflected on the impact of the cultural dimensions on the project and commercial performance of the innovation process. 
Table 4: Effect decomposition: Moderated models

\begin{tabular}{|c|c|c|c|c|c|c|}
\hline & & & \multicolumn{2}{|c|}{$\frac{\text { Model } 1}{\text { Sector type }}$} & \multicolumn{2}{|c|}{$\frac{\text { Model } 1}{\text { Ownership type }}$} \\
\hline \multicolumn{3}{|c|}{ Relationship } & Textile & Leather & Private & Public \\
\hline PODI & $-->$ & COLE & $-0.35\left(-2.75^{* *}\right)$ & $-0.33\left(-3.44^{* *}\right)$ & $-0.53\left(-6.33^{* *}\right)$ & $-0.64\left(-8.67^{* *}\right)$ \\
\hline PODI & $-->$ & SHVI & $-0.59\left(-2.88^{* *}\right)$ & $-0.79\left(-5.56^{* *}\right)$ & $-0.32\left(-3.71^{* *}\right)$ & $-0.61\left(-5.57^{* *}\right)$ \\
\hline PODI & $-->$ & OPMI & $-0.48\left(-4.67^{* *}\right)$ & $-0.62\left(-6.13^{* *}\right)$ & $-0.22\left(-3.75^{* *}\right)$ & $-0.70\left(-10.00^{* *}\right)$ \\
\hline COLL & $-->$ & COLE & $-0.63\left(-6.17^{* *}\right)$ & $-0.42\left(-5.43^{* *}\right)$ & $-0.62\left(-2.67^{* *}\right)$ & $-0.42\left(-4.11^{* *}\right)$ \\
\hline COLL & $-->$ & SHVI & $0.46\left(3.14^{* *}\right)$ & $0.46\left(4.75^{* *}\right)$ & $0.58\left(4.71^{* *}\right)$ & $0.20\left(2.71^{* *}\right)$ \\
\hline COLL & $-->$ & OPMI & $-0.49\left(-3.83^{* *}\right)$ & $-0.43\left(-3.57^{* *}\right)$ & $-0.50\left(-4.67^{* *}\right)$ & $-0.27\left(-3.75^{* *}\right)$ \\
\hline MASC & $-->$ & COLE & $0.52\left(4.22^{* *}\right)$ & $0.53\left(5.80^{* *}\right)$ & $0.37\left(2.20^{*}\right)$ & $0.46\left(3.89^{* *}\right)$ \\
\hline MASC & $-->$ & SHVI & $-0.34\left(-2.71^{* *}\right)$ & $-0.24\left(-4.00^{* *}\right)$ & $-0.38\left(-4.83^{* *}\right)$ & $-0.47\left(-4.88^{* *}\right)$ \\
\hline MASC & $-->$ & OPMI & $-0.32\left(-3.43^{* *}\right)$ & $-0.23\left(-5.25^{* *}\right)$ & $-0.32\left(-6.00^{* *}\right)$ & $-0.39\left(-5.80^{* *}\right)$ \\
\hline UNAV & $-->$ & COLE & $-0.28\left(-3.00^{* *}\right)$ & $-0.18\left(-3.25^{* *}\right)$ & $-0.26\left(-2.75^{* *}\right)$ & $-0.81\left(-5.00^{* *}\right)$ \\
\hline UNAV & $-->$ & SHVI & $-0.33\left(-2.57^{*}\right)$ & $-0.14\left(-5.00^{* *}\right)$ & $-0.24\left(-3.20^{* *}\right)$ & $-0.43\left(-4.00^{* *}\right)$ \\
\hline UNAV & $-->$ & OPMI & $-0.44\left(-3.75^{* *}\right)$ & $-0.24\left(-7.50^{* *}\right)$ & $-0.19\left(-3.00^{* *}\right)$ & $-0.43\left(-5.67^{* *}\right)$ \\
\hline COLE & $-->$ & PRPE & $0.31\left(2.86^{* *}\right)$ & $0.17\left(3.25^{* *}\right)$ & $0.46\left(3.50^{* *}\right)$ & $0.32\left(3.57^{* *}\right)$ \\
\hline COLE & $-->$ & COPE & $0.32\left(2.40^{*}\right)$ & $0.14(3.00$ & $0.25\left(2.44^{*}\right)$ & $0.18\left(3.80^{* *}\right)$ \\
\hline SHVI & $-->$ & PRPE & $0.33\left(4.67^{* *}\right)$ & $0.45\left(7.50^{* *}\right)$ & $0.86\left(11.67^{* *}\right)$ & $0.56\left(5.75^{* *}\right)$ \\
\hline SHVI & $-->$ & COPE & $0.83\left(6.36^{* *}\right)$ & $0.62\left(15.33^{* *}\right)$ & $0.94\left(18.00^{* *}\right)$ & $0.37\left(2.33^{*}\right)$ \\
\hline OPMI & $-->$ & PRPE & $0.52\left(5.00^{* *}\right)$ & $0.15\left(2.75^{* *}\right)$ & $0.62\left(6.13^{* *}\right)$ & $0.37\left(4.00^{* *}\right)$ \\
\hline OPMI & $-->$ & COPE & $0.26\left(3.75^{* *}\right)$ & $0.29\left(2.67^{* *}\right)$ & $0.49\left(7.14^{* *}\right)$ & $0.23\left(2.00^{*}\right)$ \\
\hline PODI & $-->$ & PRPE & $-0.73\left(-6.74^{* *}\right)$ & $-0.72(-9.29)$ & $-0.61\left(-5.27^{* *}\right)$ & $-0.74\left(-7.25^{* *}\right)$ \\
\hline PODI & $-->$ & COPE & $-0.55\left(-5.76^{* *}\right)$ & $-0.50\left(-8.18^{* *}\right)$ & $-0.37\left(-3.89^{* *}\right)$ & $-0.78\left(-8.06^{* *}\right)$ \\
\hline COLL & $-->$ & PRPE & $0.26(3.78)$ & $-0.22(-3.52)$ & $0.15(1.73)$ & $-0.37\left(-6.48^{* *}\right)$ \\
\hline COLL & $-->$ & COPE & $-0.18\left(-2.67^{* *}\right)$ & $-0.13(-4.31)$ & $0.23(4.28)$ & $-0.61\left(-8.08^{* *}\right)$ \\
\hline MASC & $-->$ & PRPE & $-0.20\left(-2.33^{* *}\right)$ & $-0.14\left(-3.30^{* *}\right)$ & $-0.15\left(-2.79^{* *}\right)$ & $-0.39\left(--5.44^{* *}\right)$ \\
\hline MASC & $-->$ & COPE & $-0.12(-3.53)$ & $-0.15(-4.49)$ & $-0.20\left(-2.92^{* *}\right)$ & $-0.32\left(-4.53^{* *}\right)$ \\
\hline UNAV & $-->$ & PRPE & $-0.48\left(-4.98^{* *}\right)$ & $-0.18\left(-7.57^{* *}\right)$ & $-0.26\left(-5.76^{* *}\right)$ & $-0.34\left(-5.86^{* *}\right)$ \\
\hline UNAV & $-->$ & COPE & $-0.42\left(-7.01^{* *}\right)$ & $-0.13\left(-11.45^{* *}\right)$ & $-0.36\left(-14.33^{* *}\right)$ & $-0.42\left(-13.99^{* *}\right)$ \\
\hline
\end{tabular}

\section{6}

\section{CONCLUSION}

Hofstede's four cultural dimensions [6, 10] - power distance, individualism vs collectivism, femininity vs masculinity, and uncertainty avoidance - were thoroughly examined for their impact on organisational learning and innovation performance. Nevertheless, the research relating the three bodies of knowledge - culture, organisational learning, and innovation performance - was dominated by a consideration of the western cultural environment, rather than by cross-cultural comparisons. Consequently, the applicability of the conclusions drawn from a country-specific cultural context was doubted by many scholars [1,3]. This paper examines the extent of the impact of the four cultural dimensions on the learning orientation and product innovation performance of Ethiopian manufacturing firms. Furthermore, it assesses whether sector type and ownership type makes any significant difference to the interrelationship among the three constructs. The overall result with respect to Ethiopia indicates that its current cultural setup negatively affects the learning, innovation, and innovation performance of the manufacturing firms operating there. The country's high power distance is reflected in local organisational cultures, and it was found to have a dominant effect on business activities. The result also shows that, while sector type makes no difference to the impact of national culture, ownership type plays a significant role. For that, we found the current cultural climate to have a more detrimental effect on the activities of public firms than on their private counterparts. Therefore, the manufacturing firms operating in Ethiopia need to identify the influential components of the national culture that have a negative effect on their performance, and to cultivate an internal culture that neutralises the damaging effects of the national culture [1].

Finally, the paper has limitations that need further consideration in future research if a better understanding is to be gained of the impact of national culture on the performance and learning orientation of Ethiopian manufacturers. First, due to limitations of research related to the impact of Ethiopian national culture on the performance of its manufacturing firms, the scope of the paper was limited. For that, future research needs to have a broader cross-sectional study to gain a better understanding of the interrelationships. Second, only the top and middle management members in each firm were used as data sources, and future research may need to include the opinion of low-level employees to reach a more generalised conclusion. 


\section{REFERENCES}

[1] Efrat, K. 2014. The direct and indirect impact of culture on innovation, Technovation, 34(1), pp 12-20.

[2] Martín-de Castro, G., Delgado-Verde, M., Navas-López, J.E., \& Cruz-González, J. 2012. The moderating role of innovation culture in the relationship between knowledge assets and product innovation, Technological Forecasting and Social Change, 80(2), pp 351-363.

[3] Garrett, T.C., Buisson, D.H. and Yap, C.M. 2006. National culture and R\&D and marketing integration mechanisms in new product development: A cross-cultural study between Singapore and New Zealand, Industrial Marketing Management, 35(3), pp 293-307.

[4] Sveiby, K.-E. and Simons R. 2002. Collaborative climate and effectiveness of knowledge work - An empirical study, Journal of Knowledge Management, 6(5), pp 420-433.

[5] Vecchi, A. and Brennan L. 2009. A cultural perspective on innovation in international manufacturing, Research in International Business and Finance, 23(2), pp 181-192.

[6] Hofstede, G., Hofstede, G.J. and Minkov, M. 2010. Cultures and organizations: Software of the minde. Intercultural cooperation and its importance for survival, McGraw-Hill

[7] Lewellyn, K.B. 2015. R\&D Investment in the global paper products industry: A behavioral theory of the firm and national culture perspective, Journal of International Management, 21(1), pp 1-17.

[8] Tihanyi, L., Griffith, D.A. and Russell, C.J. 2005. The effect of cultural distance on entry mode choice, international diversification, and MNE performance: A meta-analysis, Journal of International Business Studies, 36(3), pp 270-283.

[9] Dimitratos, P., Petrou, A., Plakoyiannaki, E. and Johnson, J.E. 2011. Strategic decision-making processes in internationalization: Does national culture of the focal firm matter? Journal of World Business, 46(2), pp 194-204.

[10] Hofstede, G. 1984. Culture's consequences: International differences in work-related values, Vol. 5, Sage.

[11] Kessler, E.H. 2000. Tightening the belt: Methods for reducing development costs associated with new product innovation, Journal of Engineering and Technology Management, 17(1), pp 59-92.

[12] Zakić, N., Jovanović, A. and Stamatović, M. 2008. External and internal factors affecting the product and business process innovation, Facta Universitatis-series: Economics and Organization, 5(1), pp 17-29

[13] Henard, D.H. and Szymanski, D.M. 2001. Why some new products are more successful than others, Journal of Marketing Research, 38(3), pp 362-375.

[14] Engelen, A., Brettel, M. and Wiest, G. 2012. Cross-functional integration and new product performance - The impact of national and corporate culture, Journal of International Management, 18(1), pp 52-65.

[15] Menguc, B. and Auh, S. 2010. Development and return on execution of product innovation capabilities: The role of organisational structure, Industrial Marketing Management, 39(5), pp 820-831.

[16] Laforet, S. 2008. Size, strategic, and market orientation affects on innovation, Journal of Business Research, 61(7), pp 753-764.

[17] Kok, R.A. and Biemans, W.G. 2009. Creating a market-oriented product innovation process: A contingency approach, Technovation, 29(8), pp 517-526.

[18] Senge, P.M. 2006. The fifth discipline: The art and practice of the learning organisation, Broadway Business.

[19] Dicle, Ü. and Köse, C. 2014. The impact of organisational learning on corporate sustainability and strategy formulation with the moderating effect of industry type, Procedia-Social and Behaver Science, 150, pp 958-967.

[20] Rodríguez-Pinto, J., Rodríguez-Escudero, A.I. and Gutiérrez-Cillán, J. 2012. How market entry order mediates the influence of firm resources on new product performance, Journal of Engineering and Technology Management, 29(2), pp 241-264.

[21] Lin, B.W. and Chen, J.S. 2005. Corporate technology portfolios and R\&D performance measures: A study of technology intensive firms, R\&D Management, 35(2), pp 157-170.

[22] Sinkula, J.M., Baker, W.E. and Noordewier, T. 1997. A framework for market-based organizational learning: Linking values, knowledge, and behavior, Journal of the Academy of Marketing Science, 25(4), pp 305-318.

[23] Donate, M.J. and de Pablo, J.D.S. 2015. The role of knowledge-oriented leadership in knowledge management practices and innovation, Journal of Business Research, 68(2), pp 360-370.

[24] Calantone, R.J., Cavusgil, S.T. and Zhao, Y. 2002. Learning orientation, firm innovation capability, and firm performance, Industrial Marketing Management, 31(6), pp 515-524.

[25] Wheeler, B.C. 2002. A dynamic capabilities theory for assessing net-enablement, Information Systems Research, 13(2), pp 125-146.

[26] Wang, C.L. 2008. Entrepreneurial orientation, learning orientation, and firm performance, Entrepreneurship Theory and Practice, 32(4), pp 635-657.

[27] Jiménez-Jiménez, D. and Sanz-Valle, R. 2011. Innovation, organizational learning, and performance, Journal of Business Research, 64(4), pp 408-417.

[28] Hauff, S., Richter, N.F. and Tressin, T. 2015. Situational job characteristics and job satisfaction: The moderating role of national culture, International Business Review, 24(4), pp 710-723. 
[29] Newburry, W. and Yakova, N. 2006. Standardization preferences: A function of national culture, work interdependence and local embeddedness, Journal of International Business Studies, 37(1), pp 44-60.

[30] Kirkman, B.L., Lowe, K.B. and Gibson, C.B. 2006. A quarter century of culture's consequences: A review of empirical research incorporating Hofstede's cultural values framework, Journal of International Business Studies, 37(3), pp 285-320.

[31] Hung, R.Y.Y., Yang, B., Lien, B.Y.H., McLean, G.N. and Kuo, Y.M. 2010. Dynamic capability: Impact of process alignment and organizational learning culture on performance, Journal of World Business, 45(3), pp 285-294.

[32] Hofstede, G.H. and Hofstede, G. 2001. Culture's consequences: Comparing values, behaviors, institutions and organizations across nations, Sage.

[33] Troy, L.C., Hirunyawipada, T. and Paswan, A.K. 2008. Cross-functional integration and new product success: An empirical investigation of the findings, Journal of Marketing, 72(6), pp 132-146.

[34] Shane, S.A. 1992. Why do some societies invent more than others? Journal of Business Venturing, 7(1), pp 29-46.

[35] Mihet, R. 2013. Effects of culture on firm risk-taking: A cross-country and cross-industry analysis, Journal of Cultural Economics, 37(1), pp 109-151.

[36] Robert, C., Probst, T.M., Martocchio, J.J., Drasgow, F. and Lawler, J.J. 2000. Empowerment and continuous improvement in the United States, Mexico, Poland, and India: Predicting fit on the basis of the dimensions of power distance and individualism, Journal of Applied Psychology, 85(5), pp 643-658

[37] Jones, G.K. and Davis, H.J. 2000. National culture and innovation: Implications for locating global R\& D operations, Management International Review, 40(1), pp 11-39.

[38] Griffith, D.A., Zhang, C. and Cavusgil, S.T. 2006. Attributions of non-cooperative incidents and response strategies: The role of national character, Journal of World Business, 41(4), pp 356-367.

[39] Homburg, C. and Jensen, 0. 2007. The thought worlds of marketing and sales: Which differences make a difference?, Journal of Marketing, 71(3), pp 124-142.

[40] House, R.J., Hanges, P.J., Javidan, M., Dorfman, P.W. and Gupta, V. 2004. Culture, leadership, and organizations: The GLOBE study of 62 societies, Sage Publications.

[41] Olson, E.M., Walker, O., Ruekert, R. and Bonner, J. 2001. Patterns of cooperation during new product development among marketing, operations and R\&D: Implications for project performance, Journal of Product Innovation Management, 18(4), pp 258-271.

[42] Cantwell, J. 2000. A survey of theories of international production, London: Routledge.

[43] Naranjo-Gil, D. 2009. The influence of environmental and organizational factors on innovation adoptions: Consequences for performance in public sector organizations, Technovation, 29(12), pp 810-818.

[44] Liao, S.-H., Fei, W.C. and Liu, C.T. 2008. Relationships between knowledge inertia, organizational learning and organization innovation, Technovation, 28(4), pp 183-195.

[45] Damanpour, F. and Gopalakrishnan, S. 1998. Theories of organizational structure and innovation adoption: The role of environmental change, Journal of Engineering and Technology Management, 15(1), pp 1-24.

[46] Hult, G.T.M., Snow, C.C. and Kandemir, D. 2003. The role of entrepreneurship in building cultural competitiveness in different organizational types, Journal of Management, 29(3), pp 401-426.

[47] Song, J., Wei, Y.S. and Wang, R. 2015. Market orientation and innovation performance: The moderating roles of firm ownership structures, International Journal of Research in Marketing, doi.org/10.1016/j.ijresmar.2015.03.005.

[48] Li, D., Chau, P.Y. and Lai, F. 2010. Market orientation, ownership type, and e-business assimilation: Evidence from Chinese firms, Decision Sciences, 41(1), pp 115-145.

[49] Lemma, T., Tegegne, A. and Hoekstra, D. 2012. Capacity for knowledge-based smallholder agriculture in Ethiopia: Linking graduate programs to market-oriented agricultural development: Challenges, opportunities and IPMS experience, ILRI (aka ILCA and ILRAD).

[50] Garcia-Morales, V.J., Matias-Reche, F. and Verdu-Jover, A.J. 2011. Influence of internal communication on technological proactivity, organizational learning, and organizational innovation in the pharmaceutical sector, Journal of Communication, 61(1), pp 150-17

[51] Wang, Z. and Wang, N. 2012. Knowledge sharing, innovation and firm performance, Expert Systems with Applications, 39(10), pp 8899-8908.

[52] Dillman, D.A. 1978. Mail and telephone surveys, Vol. 3, Wiley Interscience.

[53] Rhyne, L.C., Teagarden, M.B. and Van den Panhuyzen, W. 2002. Technology-based competitive strategies: The relationship of cultural dimensions to new product innovation, The Journal of High Technology Management Research, 13(2), pp 249-277.

[54] Chen, C.-J. and Huang, J.-W. 2007. How organizational climate and structure affect knowledge management - The social interaction perspective, International Journal of Information Management, 27(2), pp 104-118.

[55] Bodlaj, M. 2011. The impact of a responsive and proactive market orientation on innovation and business performance, Economic and Business Review, 12(4), pp 241-261.

[56] Bou-Llusar, J.C., Escrig-Tena, A.B., Roca-Puig, V. and Beltrán-Martín, I. 2009. An empirical assessment of the EFQM Excellence Model: Evaluation as a TQM framework relative to the MBNQA Model, Journal of Operations Management, 27(1), pp 1-22. 
[57] Fernández-Mesa, A. and Alegre, J. 2015. Entrepreneurial orientation and export intensity: Examining the interplay of organizational learning and innovation, International Business Review, 24(1), pp 148-156.

[58] Kline, R.B. 2011. Principles and practice of structural equation modeling, Guilford Press.

[59] Fornell, C. and Larcker, D.F. 1981. Evaluating structural equation models with unobservable variables and measurement error, Journal of Marketing Research, 18(1), pp 39-50.

[60] Burke, M.J., Chan-Serafin, S., Salvador, R., Smith, A. and Sarpy, S.A. 2008. The role of national culture and organizational climate in safety training effectiveness, European Journal of Work and Organizational Psychology, 17(1), pp 133-152. 